\section{J I T A A}

Journal of the Indonesian Tropical Animal Agriculture Accredited by Ditjen Penguatan Risbang No.60/E/KPT/2016
J. Indonesian Trop. Anim. Agric. pISSN 2087-8273 eISSN 2460-6278 http://ejournal.undip.ac.id/index.php/jitaa 46(3):187-198, September 2021

\title{
Caecal bacterial composition of broiler chickens affected by porang glucomannan
}

\author{
Y. N. Larasati ${ }^{1,3^{*}}$, E. Harmayani ${ }^{1,2}$, J. Widada ${ }^{1}$, N. Nurliyani ${ }^{1}$ and A. Perdinan ${ }^{3}$ \\ ${ }^{1}$ Study Program of Biotechnology, The Graduate School, Universitas Gadjah Mada, Depok, Sleman, \\ Yogyakarta, Indonesia \\ ${ }^{2}$ Department of Food and Agricultural Technology, Faculty of Agricultural Technology, Universitas \\ Gadjah Mada, Yogyakarta, Indonesia \\ ${ }^{3}$ Department of Animal Husbandry, Politeknik Pembangunan Pertanian Yogyakarta Magelang, \\ Magelang, Indonesia \\ *Corresponding E-mail: yennynikenlarasati@gmail.com
}

Received February 01, 2021; Accepted July 10, 2021

\begin{abstract}
ABSTRAK
Glukomanan tersusun dari D-glukosa dan D-manosa dengan ikatan $\beta-1,4$. Unggas tidak memiliki enzim untuk memecah ikatan $\beta$ sehingga glukomanan porang (Amorphophallus onchophyllus) dapat menjadi kandidat prebiotik untuk unggas. Penelitian ini bertujuan untuk mengetahui pengaruh glukomanan porang terhadap komposisi bakteri sekum (kemiripan, keragaman, pengelompokan bakteri) menggunakan metode Terminal Restriction Fragment Length Polymorphisms dan performan (pertambahan bobot badan, konsumsi pakan, konversi pakan) ayam broiler. Sebanyak 180 ayam broiler umur 1 hari dibagi menjadi 6 perlakuan dan 3 ulangan (masing-masing10 ekor) dengan rancangan acak lengkap. Perlakuan yang diuji adalah P0 (pakan basal), P1 (pakan basal + glukomanan porang 0,05\%), P2 (pakan basal + glukomanan porang 0,1\%), P3 (pakan basal + glukomanan porang $0,15 \%$ ), KJ (pakan basal + glukomanan konjac komersial 0,1 \%), dan KM (pakan komersial). Hasil menunjukkan bahwa komposisi bakteri sekum perlakuan glukomanan porang memiliki kemiripan dengan perlakuan glukomanan konjac dan pakan basal. Indeks diversitas dan jumlah spesies pada perlakuan glukomanan porang lebih tinggi dibandingkan glukomanan konjac. Perlakuan prebiotik glukomanan memiliki jumlah Lactobacillus yang lebih tinggi sedangkan jumlah Clostridium paling rendah diperoleh pada perlakuan glukomanan porang $0,1 \%$. Penambahan prebiotik glukomanan tidak memberikan efek negatif terhadap performan broiler.
\end{abstract}

Kata Kunci: broiler, bakteri sekum, glukomanan porang, performan

\begin{abstract}
Glucomannan is consisted of D-glucose and D-mannose with $\beta-1.4$ linkages. Poultry had no enzyme to digest $\beta$ linkage so that porang (Amorphophallus onchophyllus) glucomannan could be a prebiotic candidate. The study purposed to determine the effect of porang glucomannan on caecum bacterial composition (similarity, diversity, grouping of bacteria) using Terminal Restriction Fragment Length Polymorphisms method and performance (body weight gain, feed intake, feed conversion ratio) of
\end{abstract}


broiler chickens. One hundred and eighty unsexed day old chicks (DOC) were divided into 6 treatments and 3 replicates (10 birds each) using completely randomized design (CRD). The treatments were P0 (basal feed), P1 (basal feed $+0.05 \%$ porang glucomannan), P2 (basal feed $+0.1 \%$ porang glucomannan), P3 (basal feed $+0.15 \%$ porang glucomannan), KJ (basal feed $+0.1 \%$ commercial konjac glucomannan), and KM (commercial feed). The results showed that caecal bacterial composition of porang glucomannan treatment had similarity with konjac glucomannan and basal feed. Diversity index and species number of porang glucomannan treatment was higher than konjac glucomannan. Glucomannan prebiotics had higher Lactobacillus while the lowest Clostridium was obtained in $0.1 \%$ porang glucomannan treatment. The inclusion of glucomannan prebiotics gave no negative effect on the performance of broilers.

Keywords: broiler, caecum bacterial, porang glucomannan, performance

\section{INTRODUCTION}

Broiler chicken had short raising period, high feed efficiency, rapid weight gain, and soft meat product while the disadvantage was relatively more sensitive to an infectious disease and difficult to adapt. To overcome this condition, farmers used antibiotics as the effects of living condition, bad sanitary, and animal body weight gain. Antibiotics overuse were done to be growth promoters to increase the performance of broiler. The use of antibiotics might reduce the microbial amount in the gut that impacted more nutrient availability for the host, appeared the risk concerning the development of antimicrobial resistance and transference of antibiotic resistance genes from animal to human microflora, affected on animal performance problems and increased in the incidence of certain poultry diseases (Sugiharto, 2016). The European Commission banned feed antibiotics as growth promoters in Januari 2006 (EC Regulation No. 1831/20031). Indonesia also decided to ultimately prohibit antibiotics as feed additive in January 2018 (Minister of Agriculture Regulation No. 14/ Permentan/Pk.350/5/2017).

Other feed additives are needed to change antibiotics without threatened the performance and the welfare of poultry. Prebiotic is the safe alternative to be used. Prebiotics are nondigestible feed ingredients that beneficially affect the host by selectively altering the composition and metabolism of the gut microbiota
(Huyghebaert et al., 2011; Das et al., 2012). Nowadays, prebiotics are not only defined as certain non-digestible carbohydrates such as fructo-oligosaccharides (FOS), galactooligosaccharides (GOS), mannanoligosaccharides (MOS), but also evolve other candidates for example resistant starch (RS), lactulose, and other sources that been considered as potential prebiotics or least compounds that exhibit some characteristics that was prebiotic-like (Ricke et al., 2020).

Several studies has shown that glucomannan has a prebiotic effect on experimental animals (Wu et al., 2014; Harmayani et al., 2014). Glucomannan was composed of D-glucose monomers and D-mannose with $\beta-1.4$ linkages. The branching point is located on the $\mathrm{C}-3$ on the main chain, with a branching degree of about $8 \%$. Some acetyl units sticked in position C-6 on every 9 to 19 sugar residues (Katsuraya et al., 2003). Poultry do not have an enzyme that can digest $\beta$ linkages so glucomannan was potentially as prebiotic. Glucomannan can be extracted from porang bulb. Glucomannan contained in porang (Amorphophallus oncophyllus) is quite high 55\% dry weight (Koswara, 2013). Harmayani et al. (2014) stated that porang glucomannan could increase short chain fatty acids (SCFA), decreases potential hydrogen $(\mathrm{pH})$, and inhibits Eschericia coli growth in rat caecum. Basmacioglu et al. (2005) reported that the inclusion of esterified glucomannan may improve the performance of broiler chickens. 
Caecum is mostly placed by microbes and a key region for undigested carbohydrate fermentation bacteria to produce short chain fatty acids or SCFAs (Stanley et al., 2015; Rychlik, 2020). Several bacteria in the caecum such as Bacteroides and Blautia are involved in producing SCFAs and break down complex molecules into simpler compounds which are essential to the growth of host and gut microbiota (Lan et al., 2006; Kaakoush et al., 2014; Zhang et al., 2015). Other studies clarified that acetic acid suppresses gastric apoptosis and promotes mucin production whereas butyrate is a source of energy that promoted intestinal development and maintained the integrity of the intestinal epithelial cells (Jozefiak et al., 2004; Sun and O'Riordan, 2013; Liu et al., 2017). Bacteroides and Faecalibacterium are also involved in the health of chicken by decreasing of regulatory T-cell expansion and the stimulation of anti-inflammatory cytokine production (Kaakoush et al., 2014). The microbial community influences the structure and function of the intestine through their metabolites, the SCFAs, which have been essential for appropriate intestinal physiology and the health of gut and finally affects on performance of chickens. Porang glucomannan is expected to suppress the growth of pathogenic bacteria and promotes the growth of beneficial bacteria in the digestive tract especially caecum so performance of broiler chickens may be improved. The study aimed to determine the supplementation effect of porang glucomannan (Amorphophallus onchophyllus) compared to konjac glucomannan and commercial feed on caecum bacterial composition using terminal restriction fragment length polymorphisms (T-RFLP) method related to performance of broiler chickens.

\section{MATERIALS AND METHODS}

The study used 180 unsexed DOC broiler strain New Lohmann from PT. Japfa Comfeed. Porang glucomannan (Amorphophallus onchophyllus) was prepared from porang flour according to the method of Harmayani et al. (2014) at Faculty of Agricultural Technology, Universitas
Gadjah Mada, Yogyakarta, Indonesia. Porang flour was mixed with aquadest $(50 \mathrm{~mL} / \mathrm{g}$ flour $)$ and alumunium sulphate $(10 \% \mathrm{w} / \mathrm{w})$ for 3 minutes, heated $55^{\circ} \mathrm{C}$ for 1.5 hour until colloid was formed. Colloid was centrifuged at $3000 \mathrm{rpm}$ for 15 minutes and supernatant was obtained. Supernatant was soaked $25^{\circ} \mathrm{C}$ for 15 minutes with $95 \%$ ethanol $(25 \mathrm{~mL} / \mathrm{g}$ flour $)$ and filtered to get wet glucomannan. Drying, grinding, and shieving was done to obtain glucomannan flour. Konjac glucomannan was bought from Pyson Co., Ltd., China. The study used single phase feeding. Basal feed was formulated by the researchers in the form of mash and consisted of yellow corn, soybean meal, meat bone meal, poultry meat meal, rice bran, premix, calcium carbonate $\left(\mathrm{CaCO}_{3}\right)$, dicalcium phosphate, L-lysine, and DLmethionine (Table 1). Commercial feed in crumble form (Table 2) was obtained from feed mill company PT. Charoen Pokphand as commercial (KM) treatment was consisted of corn, rice bran, soybean meal, meat bone meal, pollard, canola, calcium, phosphorus, vitamin, trace mineral, and antioxidant. The chemical reagents were stool DNA isolation kit Favorgen, forward primer 27F universal FAM (5! AGA GTT TGA TGG CTC AG-3!), reverse primer 1492R (5! GGT TAC CTT GTA CGA CTT-3!), gotaq green master mix Promega, and restriction enzyme HaeIII.

Broiler chickens were raised until 35 days of age. A completely randomized design with 6 treatments and 3 replications (10 birds each) was arranged in the present study. The treatments applied were P0 (basal feed) as negative control, P1 (basal feed $+0.05 \%$ porang glucomannan), $\mathrm{P} 2$ (basal feed $+0.1 \%$ porang glucomannan), P3 (basal feed $+0.15 \%$ porang glucomannan), $\mathrm{KJ}$ (basal feed $+0.1 \%$ commercial konjac glucomannan) as $1^{\text {st }}$ positive control, and KM (commercial feed) as $2^{\text {nd }}$ positive control. Porang glucomannan was given every morning by mixing with a small amount of feed according to the treatment level in order to ensure that porang glucomannan totally consumed. Fed and drinking water were provided ad libitum. Body weight gain (BWG) was measured as final weight minus initial weight. Feed intake (FI) was reported by cumula- 
Table 1. Composition and Nutritional Content of Basal Feed

\begin{tabular}{|c|c|}
\hline Feedstuff & Composition (\%) \\
\hline Yellow corn & 54.00 \\
\hline Rice bran & 14.20 \\
\hline Soy bean meal & 18.00 \\
\hline Meat bone meal & 5.75 \\
\hline Poultry meat meal & 6.75 \\
\hline Dicalcium phosphate & 0.50 \\
\hline L-Lysine & 0.10 \\
\hline DL-Methionine & 0.20 \\
\hline Calcium Carbonate & 0.25 \\
\hline Premix ${ }^{4)}$ & 0.25 \\
\hline Total & 100.00 \\
\hline \multicolumn{2}{|l|}{ Nutritional content $(\%)$} \\
\hline Metabolizable energy $(\mathrm{kkal} / \mathrm{kg})^{2)}$ & $2,965.69$ \\
\hline Crude protein ${ }^{1)}$ & 21.33 \\
\hline Ether extract ${ }^{1)}$ & 4.68 \\
\hline Crude fiber ${ }^{1)}$ & 4.45 \\
\hline Methionine $^{3)}$ & 0.55 \\
\hline Lysine ${ }^{3)}$ & 1.16 \\
\hline Calcium $^{1)}$ & 1.03 \\
\hline Total phosphorus ${ }^{1)}$ & 0.71 \\
\hline \multicolumn{2}{|c|}{ 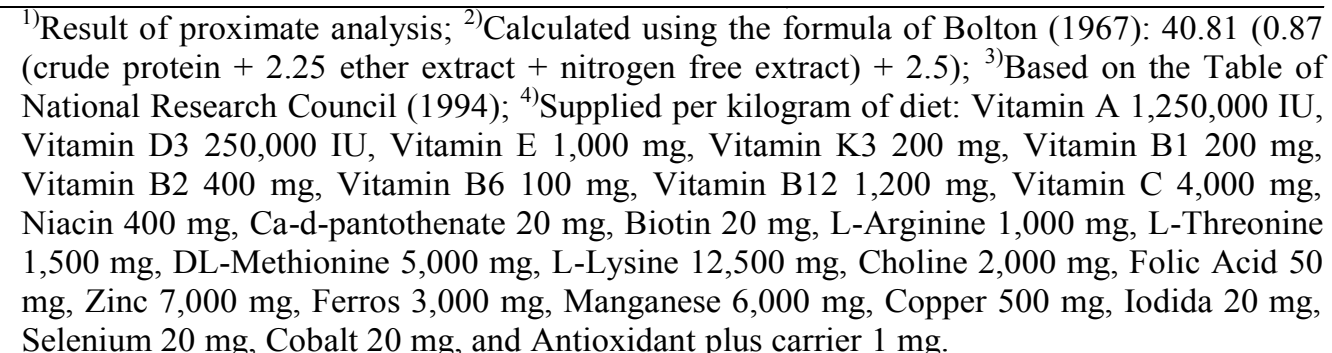 } \\
\hline
\end{tabular}

tive collections during 35 days. Feed conversion ratio (FCR) was got by dividing feed intake with the body weight gain. Three broilers for each treatment with totally 18 birds were randomly slaughtered in the $35^{\text {th }}$ day. Caecum digesta were expelled immediately and put into sterile jar for analysis of bacterial composition with T-RFLP method.

Terminal restriction fragment length polymorphisms analysis was begun with amplification of isolated DNA using PCR with a formulation of $12.5 \mu \mathrm{L}$ Gotaq Green Mix, $1 \mu \mathrm{L}$ forward primer $(27 \mathrm{~F}$ FAM), $1 \mu \mathrm{L}$ reverse primer (1492R), $1 \mu \mathrm{L}$ DNA sample (250ng), and $9.5 \mu \mathrm{L}$ nuclease free water. The PCR phase included initial denaturation $95^{\circ} \mathrm{C}$ for 5 minutes, subse- quent denaturation $95^{\circ} \mathrm{C}$ for 30 seconds, annealing $50^{\circ} \mathrm{C}$ for 30 seconds, extension $72^{\circ} \mathrm{C}$ for 2 minutes, final extension $72^{\circ} \mathrm{C}$ for 10 minutes, and 35 total cycles. The PCR product was digested with restriction enzyme HaeIII with a formulation of $2.5 \mu \mathrm{L}$ buffer R 10x, $20 \mu \mathrm{L}$ PCR product, $2 \mu \mathrm{L}$ restriction enzyme, and $0.5 \mu \mathrm{L}$ nuclease free water. The incubation was carried out at $37^{\circ} \mathrm{C}$ for 3 hours. The fragments of the digested product were sent to $1^{\text {st }}$ Base for analysis. Analysis Data of T-RFLP from $1^{\text {st }}$ Base were performed using Peak Scanner v1.0 to determine fragment profile of each sample, NTSYSPc v2.1 for similarity in the form of dendrogram, diversity index function Shannon-Weiner and Shimpson for diversity and relative abundance/ frequency 
distribution, and web based program MICA III with database RDP $16 \mathrm{~S}$ bacterial for bacterial group analysis.

\section{RESULTS AND DISCUSSION}

\section{Similarity of Caecum Bacterial Composition}

Similarity of caecum bacterial composition in all treatments were presented in Figure 1. Similarity of caecum bacterial composition of porang glucomannan $0.05 \%$ replication 2 (P1.2) and $0.1 \%$ replication $3(\mathrm{P} 2.3)$ were the highest at 0.97 . Porang glucomannan $0.15 \%$ had closeness to konjac glucomannan. Caecum bacterial composition of basal feed treatment (P0) was similar with porang glucomannan $0.1 \%$ (P2). Konjac glucomannan was closely related to commercial feed (KM). Konjac glucomannan (KJ) also had similarity with porang glucomannan. Similarity of caecum bacterial in basal feed replication 2 (P0.2) was the lowest.

Dendrogram of similarity in bacterial composition based on the TRF profile resulting from restriction enzyme HaeIII were presented in Figure 1. The results showed that the similarity of porang glucomannan $0.05 \%$ of replication 2 (P1.2) and $0.1 \%$ of replication $3(\mathrm{P} 2.3)$ the highest was 0.97 . It meant that the caecum bacterial composition of broiler chickens which were given porang glucomannan $0.05 \%$ had a close relationship with the composition of the bacterium of broiler caecum chickens which were given porang glucomannan $0.1 \%$. Porang glucomannan $0.15 \%$ showed a close relationship with glucomannan konjac which could be seen in the treatment groups P3.1, P3.2 and KJ.1, KJ.3. The similarity of basal feed (P0) treatment was closer to $0.1 \%$ porang glucomannan (P2). Glucomannan konjac had closeness to commercial feed (KM). It was shown in dendrogram KJ.3 and KM.2 with similarity of 0.97 . The results indicated that the bacterial composition in konjac glucomannan $(\mathrm{KJ})$ was similar to the bacterial composition in commercial feed (KM). Glucomannan konjac $(\mathrm{KJ})$ also closely related with porang glucomannan. The similarity of the caecum bacteria in the

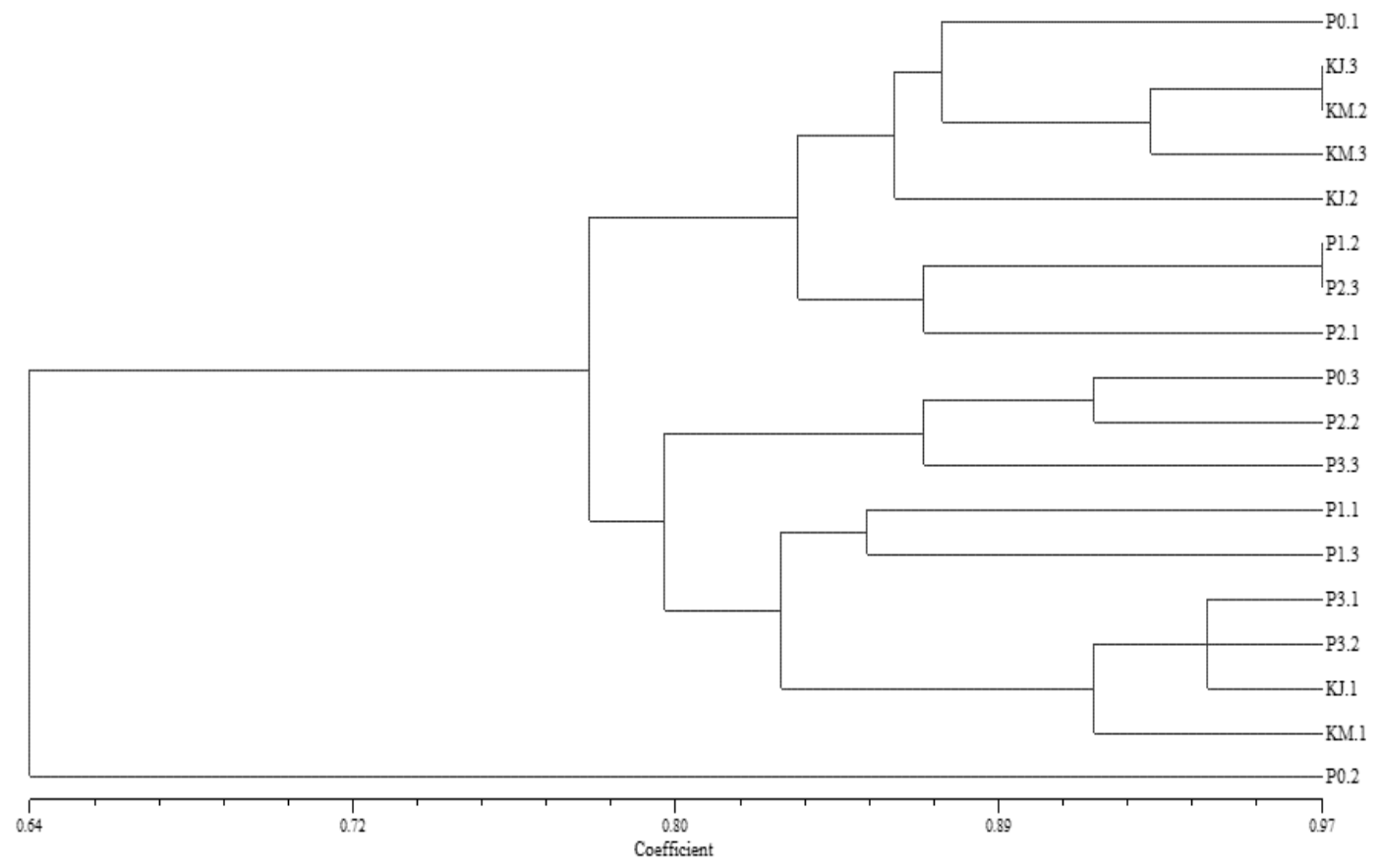

Figure 1. Similarity dendrogram of caecum bacterial composition with terminal restriction length fragment polymorphism method restricted by HaeIII enzyme. Note: P0.1: P0 replication 1; P0.2: P0 replication 2; P0.3: P0 replication 3; P1.1: P1 replication 1; P1.2: P1 replication 2; P1.3: P1 replication 3; P2.1: P2 replication 1; P2.2: P2 replication 2; P2.3: P1 replication 3; P3.1: P3 replication 1; P3.2: P1 replication 2; P3.3: P3 replication 3; KJ.1: KJ replication 1; KJ.2: KJ replication 2; KJ.3: KJ replication 3; KM.1: KM replication 1; KM.2: KM replication 2; KM.3: KM replication 3. 
Table 2. Chemical Composition of Broiler Commercial Feed

\begin{tabular}{lcc}
\hline \multicolumn{1}{c}{ Nutritional contents } & Composition \\
\hline Water content (\%) & Max & 13 \\
Crude protein (\%) & & $21.5-23.8$ \\
Ether extract (\%) & Min & 5.0 \\
Crude fiber (\%) & Max & 5.0 \\
Ash (\%) & Max & 7.0 \\
Calcium (\%) & Min & 0.9 \\
Phosphorus (\%) & Min & 0.6 \\
Metabolizable energy (kkal/kg) & & $3,025-3,125$ \\
\hline Source: PT Charoen Pokhpand & &
\end{tabular}

replicate basal feed 2 (P0.2) was the lowest.

\section{Diversity of Caecum Bacterial Composition}

Diversity index of caecum bacterial composition for all treatments were included in the category of moderate diversity (Table 3 ). Porang glucomannan $0.05 \%$ replication $3(\mathrm{P} 1)$ had the highest diversity index (1.88) compared with other porang glucomannan level. It showed that the diversity of species in the addition of $0.05 \%$ porang glucomannan in the feed could increase the type and number of species. Basal diet (P0) showed the highest diversity index and number of species each 2.10 and 12 .

The Shannon Wiener and Shimpson Diversity Index was used to describe variety of organisms. According to Bibi and Ali (2013), the Shannon Wiener and Shimpson Diversity Index estimated the evenness and richness of species in a composition of microbes. Shannon-Wiener Index $\left(\mathrm{H}^{\prime}\right)$ primarily reflects evenness relative to richness ( $\geq 3: 1$ ) (Strong, 2016). The greater value indicated more abundant and diverse species in the bacterial composition.

\section{Grouping of Caecum Bacterial Composition}

Grouping of caecum bacterial composition were shown in Figure 2. Porang glucomannan $0.05 \%$ (P1) had bacterial composition Lactobacillus, Clostridium, Uncultured Rumen Bacterium, Bacteroides, Uncultured Bacterium, Brachybacterium, Butyrivibrio, Corynebacterium, Bifidobacterium, and unidentified. Porang glucomannan $0.1 \%(\mathrm{P} 2)$ consisted of Lactobacillus, Clostridium, Bacteroides, Uncultured Rumen Bacterium, Uncultured Bacterium, Butyrivibrio, Enterococcus, Uncultured Beta Proteobacterium, Bacillus, and unidentified. Bacterial composition of $0.15 \%$ porang glucomannan (P3) treatment were Lactobacillus, Clostridium, Bacteroides, Uncultured Rumen Bacterium, Uncultured Bacterium, Uncultured Beta Proteobacterium, and unidentified. Basal feed (P0) had Lactobacillus, Clostridium, Uncultured Rumen Bacterium, Uncultured Bacterium, Uncultured Beta Proteobacterium, Uncultured Alpha Proteobac-

Table 3. Shannon Wiener dan Shimpson diversity index of caecum bacterial composition with terminal restriction length fragment polymorphism method restricted by HaeIII enzyme

\begin{tabular}{lcc}
\hline \multicolumn{1}{c}{ Treatment } & $\mathrm{S}^{\mathrm{a}}$ & $\mathrm{H}^{\mathrm{b}}$ \\
\hline Basal feed (P0) & 12 & 2.10 \\
Porang glucomannan $0.05 \%(\mathrm{P} 1)$ & 8 & 1.88 \\
Porang glucomannan $0.1 \%(\mathrm{P} 2)$ & 7 & 1.83 \\
Porang glucomannan $0.15 \%(\mathrm{P} 3)$ & 7 & 1.56 \\
Konjac glucomannan $(\mathrm{KJ})$ & 7 & 1.39 \\
Commercial feed (KM) & 6 & 1.60 \\
\hline
\end{tabular}

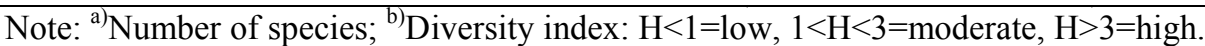


terium, Enterobacteriaceae Bacterium, Uncultured Bacillus, Uncultured Alkalinindiges, Staphylococcus, and unidentified. Bacterial composition of Konjac glucomannan (KJ) treatment consisted of Lactobacillus, Clostridium, Uncultured Rumen Bacterium, Uncultured Streptococcus, Bacillus, and unidentified. While composition of bacterial in commercial feed (KM) were Lactobacillus, Clostridium, Uncultured Rumen Bacterium, Uncultured Bacterium, uncultured Bacterioidetes, Ruminococcus, and unidentified.

Caecum was the habitat mostly placed by microbes and had a higher bacterial diversity than the upper digestive tract around $10^{10} \mathrm{CFU}$ per gram and approximately 1000 different species (Rychlik, 2020). Caecum was a key region for undigested carbohydrate fermentation bacteria and a major site for colonization of pathogens (Stanley et al., 2015). Research by Gong et al. (2007), caecum was mainly inhabited by the genus Clostridia followed by Lactobacillus and Ruminococcus. Clostridium and Lactobacillus were present in all treatments. At the species level, amount of L. crispatus, L. johnsonii, L. sali-

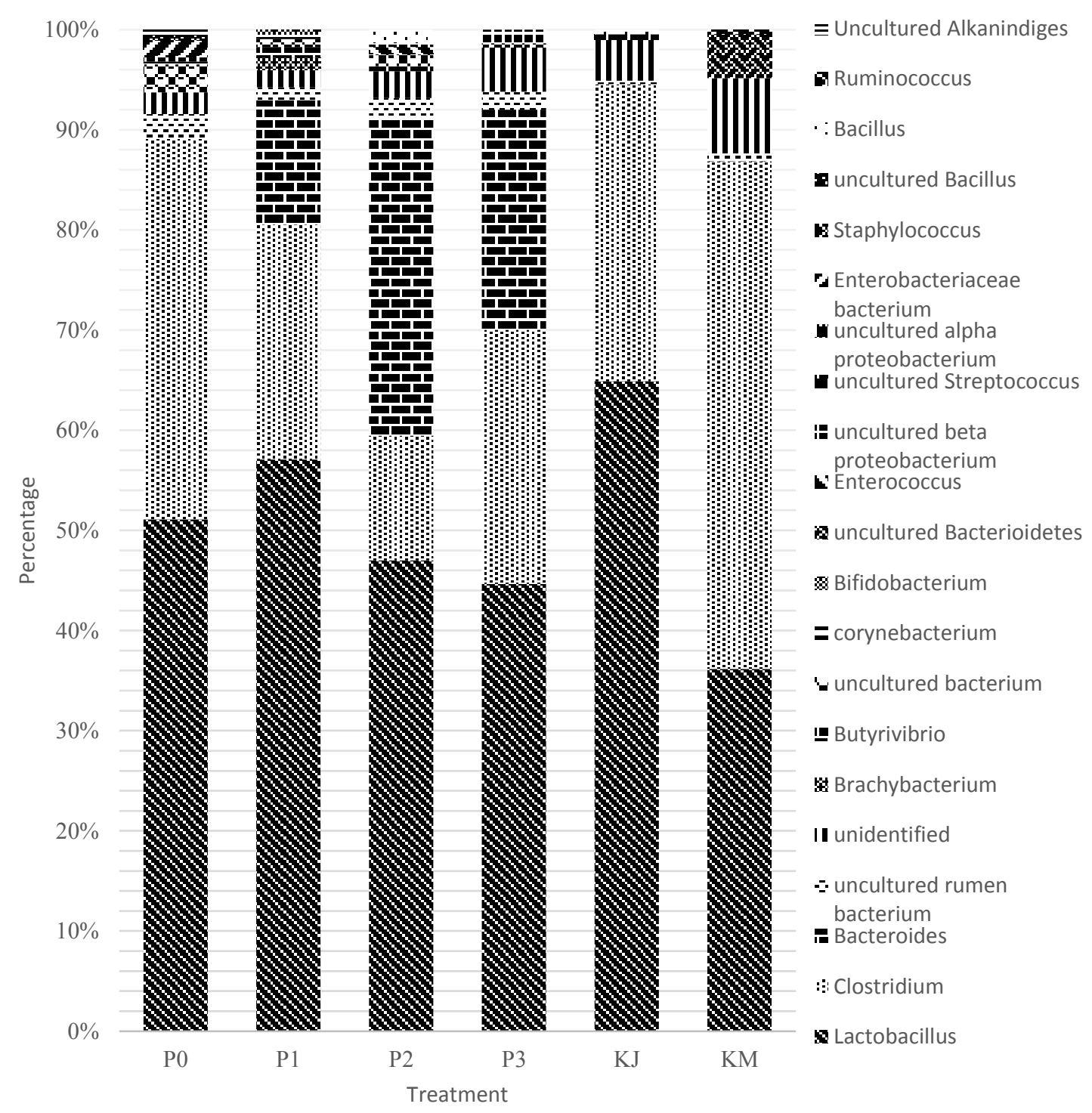

Figure 2. Grouping of caecum bacterial composition with terminal restriction length fragment polymorphism method restricted by HaeIII enzyme. Note: P0 (basal feed), P1 (0.05\% porang glucomannan), P2 (0.1\% porang glucomannan), P3 (0.15\% porang glucomannan), KJ (0.1\% commercial konjac glucomannan), and KM (commercial feed). 
varius, and $L$. reuteri was $40 \%$ of the caecum microbiota (Stanley et al., 2015). The results showed that the Lactobacillus bacteria in the broiler caecum of all treatments were in the range of $35-56 \%$ (Figure 2). Supplementation of $0.05 \%$ porang glucomannan $(\mathrm{P} 1)$ in broiler chicken feeds showed higher percentage of Lactobacillus compared with $0.1 \%$ porang glucomannan (P2), $0.15 \%$ porang glucomannan (P3), basal feed (P0) and commercial feed (KM). While the addition of konjac glucomannan had the highest percentage of Lactobacillus. In addition to Lactobacillus, other lactic acid bacteria which were predicted to be present in porang glucomannan treatment but not in other treatments were Bifidobacterium and Enterococcus. Bacteria of Enterococcaceae had been reported in caecum microbiota (Yin et al., 2010). Enterococcus was obtained in the treatment of $0.1 \%$ porang glucomannan (P2) and Bifidobacterium in $0.05 \%$ porang glucomannan (P1). Uncultured Streptococcus and Bacillus were obtained in the glucomannan konjac (KJ) treatment.

The only bacterium predicted to exist in basal feed was Enterobacteriaceae Bacterium. Bacteroides was only presented in the porang glucomannan treatments (Figure 2). Commercial feed had uncultured Bacterioidetes. Oakley et al. (2014) stated that Enterobacteriaceae and Bacteroidaceae were also found in the caecum of broiler chicken. Caecum was a fermentation organ of chicken to produce the highest SCFAs such as acetic, propionic, and butyric acid than duodenum, jejunum, and ileum which played an important role in animal health (Liao et al., 2020). Butyrivibrio bacteria belonging to cellulolytic bacteria was only obtained in the treatment of porang glucomannan. The cellulolytic bacteria, Butyrivibrio, was obtained on porang glucomannan $0.05 \%$ and $0.1 \%$. The bacteria was not found on other treatments except porang glucomannan. This bacteria was included in the phylum Firmicutes and involved in the fermentation process of the caecum to produce butyric acid (Eeckhaut et al., 2011).

Lactobacillus, Clostridium, Uncultured Rumen Bacterium, and unidentified bacteria existed in all treatments. Lactobacillus in porang glucomannan $0.05 \%(\mathrm{P} 1)$ showed a percentage increasing compared with basal feed and commercial feed treatments but decreasing compared with conjac glucomannan. However, other lactic acid bacteria were found in porang glucomannan whereas in other treatments none such as Bifidobacterium existed in porang glucomannan $0.05 \%$ (P1). This indicated that the inclusion of porang glucomannan could increase the number and type of beneficial bacteria in the digestive tract such as Lactobacillus and Bifidobacterium. Abdel-Raheem et al. (2012) stated that giving Mannan-oligosaccharides (MOS) could improve Lactobacilli in broiler 42 days. Xylooligosaccharide (XOS) had also been investigated in chickens to increase the proportion of Lactobacillus in caecum (Pourabedin et al., 2015). According to Nabizadeh (2012), addition of inulin in the diet raised the amount of Bifidobacteria in broiler chickens significantly. Putri et al. (2017) said

Table 4. Performance of Broiler Chickens in Experimental Treatments

\begin{tabular}{|c|c|c|c|c|c|c|}
\hline \multirow[t]{2}{*}{ Parameters } & \multicolumn{5}{|c|}{ Treatments } & \multirow[b]{2}{*}{$\mathrm{KM}$} \\
\hline & $\mathrm{P} 0$ & $\mathrm{P} 1$ & $\mathrm{P} 2$ & P3 & $\mathrm{KJ}$ & \\
\hline BWG (g/bird) & $1,445.12^{b}$ & $1,497.44^{\mathrm{b}}$ & $1,522.85^{\mathrm{b}}$ & $1,468.74^{\mathrm{b}}$ & $1,460.75^{\mathrm{b}}$ & $2,014.50^{\mathrm{a}}$ \\
\hline FI (g/bird) & $2,449.06^{\mathrm{b}}$ & $2,396.49^{b}$ & $2,503.74^{\mathrm{b}}$ & $2,409.76^{\mathrm{b}}$ & $2,508.61^{b}$ & $2,683.58^{\mathrm{a}}$ \\
\hline FCR & $1.69^{\mathrm{a}}$ & $1.61^{\mathrm{a}}$ & $1.65^{\mathrm{a}}$ & $1.64^{\mathrm{a}}$ & $1.72^{\mathrm{a}}$ & $1.33^{\mathrm{b}}$ \\
\hline
\end{tabular}

P0 (basal feed), P1 (0.05\% porang glucomannan), P2 (0.1\% porang glucomannan), P3 (0.15\% porang glucomannan), KJ (0.1\% commercial konjac glucomannan), and KM (commercial feed). ${ }^{\mathrm{a}-\mathrm{b}}$ Mean values in the same row with different superscript differ significantly $(\mathrm{P}<0.05)$. 
that MOS prebiotic triggered the number of lactid acid bacteria in broiler during 28 days old. Perdinan et al. (2019) also stated that porang glucomannan increased lactid acid bacteria in broiler chickens.

The percentage of Clostridium in porang glucomannan treatments was lower than other treatments. It was in accordance with Kim et al. (2011) which stated that giving prebiotic $0.25 \%$ FOS and $0.05 \%$ MOS in broiler could decrease population of Clostridium perfringens and Escherichia coli and increase Lactobacilli. Park et al. (2015) said that Salmonella, Escherichia coli, and Clostridium perfringens were bacteria that could infect chicken's digestive tract. Perdinan et al. (2019) also stated that porang glucomannan decreased coliform in 35 days old of broiler.

The source of diet composition and rearing system influenced the bacteria in the gut (Visscher et al., 2017; Hou et al., 2020). The study used different diet composition source but same rearing system and similar nutritional content between basal feed and commercial feed. Drew et al. (2004) and Vissher et al. (2017) reported different source of protein in feed affected on population of Clostridium perfringens and Campylobacter spp. in the caecum of broiler because the amount and kind of amino acids determined growth of the bacteria although the diets had same protein level. Ravangard et al. (2017) used step down protein in their research and stated that caecum bacterial counts, Lactobacillus and Escherichia coli counts, were significantly not influenced by different nutritional content but only affected by inclusion of feed additive. In line with this study, the difference in the composition of the caecum microbiota might be caused by the addition of feed additive between control and prebiotics treatments while diet composition source of feed between basal and commercial feed.

\section{Performance}

This study used single phase feeding. Dawood and Mohammed (2015) proved that single phase feeding could improve performance of broilers such as final body weight, total body weight gain, and feed conversion ratio compared to two or three diets phase feeding. Another statement said that the use of single phase feeding in broiler might just be a solution to the problem of feed cost in chicken production and simplify to be adopted and practiced by the people who could not afford commercially manufactured feed for their birds (Muhammad et al., 2016).

Performance data was presented in Table 4. The results showed that treatments of P0, P1, $\mathrm{P} 2, \mathrm{P} 3$, and $\mathrm{KJ}$ were significantly different $(\mathrm{P}<0.05)$ than $\mathrm{KM}$ on body weight gain, feed intake, and feed conversion ratio of broiler chickens. Body weight gain and feed intake of broilers supplemented with prebiotics and control were lower than commercial feed. Prebiotics and control treatments had higher FCR compared to commercial feed. Basal feed and commercial feed had similar nutritional contents but the form of feed was different between mash and crumble. Form of feed influenced performance of broiler. This study was in agreement with the findings of Al-Nasrawi (2016) and Kuleile and Molapo (2019) that broilers given with crumble feed could improve performance on BWG, FI, and FCR than mash feed because crumble increased available dietary energy for BWG, which improved feed efficiency by reducing the time spent eating and increasing the time spent resting. Additionally, the higher growth rate of birds fed crumble diet was accompanied by reduction in energy release during feed consumption that allowed for an increase in productive energy value of the diet, thus providing more calories in growing birds.

There was no significant difference on performance between prebiotics ( $\mathrm{P} 1, \mathrm{P} 2, \mathrm{P} 3, \mathrm{KJ})$ and control (P0). The result was supported by Sarangi et al. (2016) that the inclusion of prebiotic MOS in broiler had no significant effect on body weight gain. Elrayeh and Yildiz (2012) also proved that prebiotics inulin and $\beta$-glucan did not impact on FI and FCR. In this study, broilers were fed with same nutritional contents and form of feed between prebiotics and control treatments. Supported by Utami and Wahyono (2019) 
that performance of broilers supplemented with feed additives were not significantly different because the diet composition had same protein and energy of feed. Falaki et al. (2011) also reported that feed additives might impact in unfavorable management or environmental conditions.

\section{CONCLUSION}

Treatments of glucomannan porang and konjac could increase Lactobacillus compared to control and commercial feed. The lowest Clostridium was obtained in $0.1 \%$ porang glucomannan treatment. The inclusion of glucomannan prebiotics had no negative effect on performance of broilers.

\section{REFERENCES}

Abdel-Raheem, S. M., S. Abd-Allah, and K. Hassanein. 2012. The effects of prebiotic, probiotic and synbiotic supplementation on intestinal microbial ecology and hystomorphology of broiler chickens. IJAVMS. 6(4):277-289.

Al-Nasrawi, M. A. M. 2016. The impact of different dietary forms (mash, crumble and pellets) on some growth traits and carcass characteristics of broilers. J. Anim. Health Prod. 4(2):31-36.

Basmacioglu, H., H. Oguz, M. Ergul, R. Col, and Y. O. Birdane. 2005. Effect of dietary esterified glucomannan on performance, serum biochemistry and haematology in broilers exposed to aflatoxin. Czech $\mathrm{J}$. Anim. Sci. 50(1):31-39.

Bibi, F. and Z. Ali. 2013. Measurement of diversity indices of avian communities at taunsa barrage wildlife sanctuary. Pak. J. Anim. Plant Sci. 23(2):469-474.

Bolton, W. 1967. MAFF Bulletin. No.174. Poultry Nutrition. HMSO, London.

Das, L., E. Bhaumik, U. Raychaudhuri, and R. Chakraborty. 2012. Role of nutraceuticals in human health. J. Food Sci. Technol. 49:173-183.
Dawood, H. Y. and O. E. A. Mohammed. 2015. Effect of phase feeding on broiler performance and serum-carcass lipids. Am. J. Innov. Res. Appl. Sci. 2429(5396):267273.

Drew, M. D., N. A. Syed, B. G. Goldade, B. Laarveld, and A. G. Van Kessel. 2004. Effects of dietary protein source and level on intestinal populations of clostridium perfringens in broiler chickens. Poult. Sci. 83:414-420.

Eeckhaut, V., F. V. Immerseel, S. Croubels, S. D. Baere, F. Haesebrouck, R. Ducatelle, P. Louis, and P. Vandamme. 2011. Butyrate production in phylogenetically diverse firmicutes isolated from the chicken caecum. Microbiol. Biotechnol. 4(4):503-512.

Elrayeh, A. S. and G. Yildiz. 2012. Effects of inulin and $\beta$-glucan supplementation in broiler diets on growth performance, serum cholesterol, intestinal length, and immune system. Turk. J. Vet. Anim. Sci. 36:388-394.

Falaki, M., M. S. Shargh, B. Dastar, and S. Zerehdaran. 2011. Effects of different levels of probiotic and prebiotic on performance and carcass characteristics of broiler chickens. J. Anim. Vet. Adv. 9:2390-2395.

Gong, J., W. Si, and R. J. Forster. 2007. 16S rRNA gene-based analysis of mucosaassociated bacterial community and phylogeny in the chicken gastrointestinal tracts: from crops to ceca. FEMS Microbiol. Ecol. 59:147-57.

Harmayani, E., V. Aprilia, and Y. Marsono. 2014. Characterization of glucomannan from Amorphophallus oncophyllus and its prebiotic activity in vivo. Carbohydr. Polym. 112(2014):475-479.

Hou, L. Y., B. S. Sun, and Y. Yang. 2020. Effects of added dietary fiber and rearing system on the gut microbial diversity and gut health of chickens. Animals. 10:107.

Huyghebaert, G., R. Ducatelle, and F. Van Immerseel. 2011. An update on alternatives to antimicrobial growth promoters for broilers. Vet. J. 187:182-188. 
Jozefiak, D., A. Rutkowski, S. A. Martin, and S. 2004. Carbohydrate fermentation in the avian ceca: a review. Anim. Feed Sci. Tech. 113:1-15.

Kaakoush, N. O., N. Sodhi, J. W. Chenu, J. M. Cox, S. M. Riordan, and H. M. Mitchell. 2014. The interplay between Campylobacter and Helicobacter species and other gastrointestinal microbiota of commercial broiler chickens. Gut Pathog. 6(18):1-10.

Katsuraya, K., K. Okuyama, K. Hatanaka, R. Oshima, T. Sato, and K. Matsuzaki. 2003. Constitution of konjac glucomannan: chemical analysis and $13 \mathrm{c} \mathrm{nmr}$ spectroscopy. Carbohydr. Polym. 53(2003):183-189.

Kim, G. B., Y. M. Seo, C. H. Kim, and I. K. Paik. 2011. Effect of dietary prebiotic supplementation on the performance, intestinal microflora, and immune response of broilers. Poult. Sci. 90:75-82.

Koswara, S. 2013. Teknologi Pengolahan Umbiumbian Bagian 2: Pengolahan Umbi Porang. Southeast Asian Food and Agricultural Science and Technology (SEAFAST) Center, Bogor Agricultural University, Bogor.

Kuleile, N. and S. Molapo. 2019. The influence of feed form on broiler production and gastrointestinal tract development. Online J. Anim. Feed Res. 9(1): 38-43.

Lan, P. T. N., M. Sakamoto, S. Sakata, and Y. 2006. Benno. Bacteroides barnesiae sp. nov., Bacteroides salanitronis sp. nov. and Bacteroides gallinarum sp. nov., isolated from chicken caecum. Int. J. Syst. Evol. Microbiol. 56:2853-2859.

Liao, X., Y. Shao, G. Sun, Y. Yang, L. Zhang, Y. Guo, X. Luo, and L. Lu. 2020. The relationship among gut microbiota, shortchain fatty acids, and intestinal morphology of growing and healthy broilers. Poult. Sci. 99:5883-5895.

Liu, J., J. Wang, Y. Shi, W. Su, J. Chen, Z. Zhang, G. Wang, and F. Wang. 2017. Short chain fatty acid acetate protects against ethanol-induced acute gastric mucosal lesion in mice. Biol. Pharm. Bull.
40:1439-1446.

Muhammad, A. S., A. M. Umar, M. A. Mujitaba, I. Abdu, and D. Ajayi. 2016. Single phase feeding of fishmeal and its influence on growth and carcass of broiler chickens. Bulletin of Anim. Health Product. Africa. 64(4):409-413.

Nabizadeh, A. 2012. The effect of inulin on broiler chicken intestinal microflora, gut morphology, and performance. J. Anim. Feed Sci. 21:725-734.

National Research Council. 1994. Nutrient Requirements of Poultry 9th Revised Ed. National Academic Press, Washington DC.

Oakley, B. B., H. S. Lillehoj, M. H. Kogut, W. K. Kim, J. J. Maurer, A. Pedroso, M. D. Lee, S. R. Collett, T. J. Johnson, and N. A. Cox. 2014. The chicken gastrointestinal microbiome. FEMS Microbiol. Lett. 360 (2014):100-112.

Park, S., D. Kim, J. Kim, and Y. Moon. 2015. Effect of mycotoxins on mucosal microbial infection and related pathogenesis. Toxins. 7:4484-4502.

Perdinan, A., H. I. Wahyuni, and N. Suthama. 2019. Body resistance and growth performance of broiler fed glucomannan extracted from Amorphophallus Onchophyllus tuber. Trop. Anim. Sci. J. 42(1):33-38.

Pourabedin, M., L. Guan, and X. Zhao. 2015. Xylo-oligosaccharides and virginiamycin differentially modulate gut microbial composition in chickens. Microbiome. 3:1-12.

Putri, A. N. S, Sumiati, and A. Meryandini. 2017. Effect of dietary mannanoligosaccharides from copra meal on intestinal microbes and blood profile of broiler chickens. J. Indonesian Trop. Anim. Agric. 42(2):109-119.

Ravangard, H., M. Houshmand, M. Khajavi, and R. Naghiha. 2017. Performance and cecal bacteria counts of broilers fed low protein diets with and without a combination of probiotic and prebiotic. Braz. J. Poult. Sci. 2017:75-82.

Ricke, S. C., S. I. Lee, S.A. Kim, S. H. Park, and Z. Shi. 2020. Prebiotics and the poultry 
gastrointestinal tract microbiome. Poult. Sci. 99:670-677.

Rychlik, I. 2020. Composition and function of chicken gut microbiota. Animals. 10 (103):1-20.

Sarangi, N. R., L. K. Babu, A. Kumar, C. R. Pradhan, P. K. Pati, and J. P. Mishra. 2016. Effect of dietary supplementation of prebiotic, probiotic, and synbiotic on growth performance and carcass characteristics of broiler chickens. Vet. World. 9:313-319.

Stanley, D., M. S. Geier, and S. E. Denman. 2013. Identification of chicken intestinal microbiota correlated with the efficiency of energy extraction from feed. Vet. Microbiol. 164:85-92.

Strong, W. L. 2016. Biased richness and evenness relationships within Shannon-Wiener index values. Ecol. Indic. 67:703-713.

Sugiharto, S. 2016. Role of nutraceuticals in gut health and growth performance of poultry. J. Saudi Soc. Agric. Sci. 15:99-111.

Sun, Y., and M. X. D. O'Riordan. 2013. Regulation of bacterial pathogenesis by intestinal short-chain fatty acids. Adv. Appl. Microbiol. 85:93-118.

Utami, M. M. D. and N. D. Wahyono. 2019.
Supplementation of probiotic and prebiotic on the performance of broilers. IOP Conf. Series: Earth Environ. Sci. 207:1-6.

Visscher, C. F., A. Abd El-Wahab, M. F. E. Ahmed, J. Hankel, V. Taube and J. Kamphues. 2017. Influence of different protein sources in the broiler diet on the presence of Campylobacter spp. in excreta and caecal content. J. Anim. Physiol. Anim. Nutr. 101(1):95-104.

Wu, W. T., L. C. Yang, and H. L. Chen. 2014. Effects of konjac glucomannan, inulin and cellulose on acute colonic responses to genotoxic azoxymethane. Food Chem. 155 (2014):304-310.

Yin, Y., F. Lei, and L. Zhu. 2010. Exposure of different bacterial inocula to newborn chicken affects gut microbiota development and ileum gene expression. ISME J. 4:367-376.

Zhang, X., Y. Zhao, J. Xu, Z. Xue, M. Zhang, X. Pang, X. Zhang, and L. Zhao. 2015. Modulation of gut microbiota by berberine and metformin during the treatment of high-fat diet-induced obesity in rats. Sci. Rep. 14405(5):1-10. 